\title{
The Analysis of Consumer Preferences on Mulberry Leaves Tea as An Antioxidant-Enriched Product
}

\author{
Aisyah Larasati ${ }^{1}$ \\ Issutarti $^{2}$ \\ 1,2 Malang State University, Indonesia
}

\begin{abstract}
One alternative product innovation made of mulberry leaves is the mulberry leaves tea that served in a ready to drink pack. This alternative innovation is expected to increase the economic value of mulberry leaves. The product of mulberry leaves tea is made by adding $30 \%$ sappan wood of the total weight of mulberry tea in order to improve the color appearances of the tea. The purpose of this research is to analyze the consumer preferences on mulberry leaves tea as an antioxidant-enriched product. The consumer preferences on the aroma, color, and taste of mulberry tea were tested by 100 panelists. The results show that the top five important attributes of mulberry tea are color, aroma, taste, packaging, and price. In addition, the preferences test show that $48 \%$ of the panelist like the color (light brown) and the aroma of the tea (rather strong of lime aroma). The preference test also shows that $45 \%$ of the consumer is rather like the taste (a little bit sour). As a conclusion, in order to increase consumer preferences on the mulberry tea, the taste of the tea should be improved by conducting further research to determine the proper amount of lime used in the tea formulation.
\end{abstract}

Field of Research: consumer preferences, product innovation, mulberry tea

\section{INTRODUCTION}

Antioxidants are compounds that can inhibit oxidation reactions by binding free radicals and highly reactive molecules so that cellular damage in the body can be inhibited (Winarsi, 2007). Oxidant levels in the human body can be higher than it should be if the person has an unhealthy lifestyle and lives in an unhealthy environment, such as an environment with high air pollution. Thus, there is a need for antioxidants to protect the human body from diseases caused by free radicals. Antioxidants may come from inside the body (primary source) and from outside the body (secondary source). Sometimes the antioxidants that come from inside the body are unable to cope with excessive oxidative stress, so the human body takes antioxidants that come from outside the body. According to Winarsi (2007), secondary antioxidants can be obtained from foods containing antioxidant compounds such as vitamin C, E, B-carotene, flavonoids, isoflavones, flavones, anthocyanins, etc.

Mulberry leaves are known as silkworm feed in Indonesia. The use of mulberry leaves as human food ingredients has not been common yet even though mulberry leaves have many advantages. According to Frank \& Orwell (2013), mulberry leaves have a very powerful antioxidant effect. The antioxidant effect comes from the polyphenolic compounds contained in the leaves. The most polyphenolic compounds presented in mulberry leaves are flavonoids, such as quercetin, kaempferol, and morin (Frank \& Orwell, 2013). Flavonoid compounds function as antioxidants that can inhibit the clumping of blood cells, stimulating the production of nitric oxide (NO), which plays a role in dilating blood vessels and inhibit cancer growth (Winarsi, 2007). 
According to Riadi (2014), polyphenols are water-soluble compounds. The utilization of mulberry leaves as tea can be an alternative of an extraction effort of polyphenol content in mulberry leaves so that people can make use of its positive effect on health. In addition, through beverages such as tea, other bioactive components found in mulberry leaves can also be absorbed rapidly by the body after consumption.

Tea is a favorite drink that is consumed by all ages. In worldwide, the total consumption of tea is higher than the consumption of other drink such as soft drink, coffee, and alcoholic beverages (Agustina, 2015). Types of tea that is widely consumed in Indonesia is tea in the packaging and tea leaves. According to data from the Association of Light Beverage Industry (ASRIM) in Agustina (2015), the amount of packaged tea consumption in Indonesia at 2014 reaches 2 billion liters or 1.07 pounds $(0.5 \mathrm{~kg})$ of tea leaves per person annually. The data shows that the tea in the packaging becomes the second highest ready-drink consumed after mineral water.

According to Winarti (2010), tea is a drink made by brewing leaves, leaf shoots, or stem of tea plants (camellia sinesis) dried with hot water. The term 'tea' is also defined as beverages made by brewing dried fruits, spices or other medicinal plants (Winarti, 2010: 201). One of the ingredients that can be used as tea is mulberry leaves. According to Frank \& Orwell (2013), mulberry leaves have a very powerful antioxidant effect. As an effort to improve quality mulberry leaves tea color, this study adds food coloring into mulberry tea. Sappan wood is one of the natural red dye. The red color that comes out the sappan wood comes from brazilin, one of the flavonoid compounds (Nirmal et al, 2015). In addition to the dye, the addition of sappan wood is also conducted in order to increase the content of antioxidants in mulberry leaf tea drinks. The use of a combination of antioxidants has been shown to increase antioxidant activity compared to when used separately.

The utilization of mulberry leaves as tea in a ready-to-drink packaging is one of the innovation to get the benefits in terms of health as well as to fulfill consumers need in practical mode consumption. In addition to product innovation, another thing to plan in order to achieve marketing goals is the implementation of marketing strategies based on the marketing mix, a combination of product, pricing, promotional activities, and distribution systems that are at the core of the company's marketing system (Swastha \& Sukotjo, 2002). The four variables are the determinants of the success rate of the company marketing strategy.

The product mix is everything that can be offered in the market to get customer attention, demand, usage or consumption that can fulfill the customer desire or need (Kotler \& Armstrong, 2001: 346). The product mix is the initial variable that needs to be planned before the other variables because in the absence of the product there is nothing to be marketed. Each product has certain characteristics so that a product can be distinguished from other similar product, such as quality/quality, brand, and packaging. The product mix is also an important factor that influences customer preferences on a certain product.

This paper examines the consumer preferences and the product mix of mulberry leaves tea products, in the form of a ready-to-drink tea, which includes 
product quality in terms of organoleptic properties (color, flavor, taste), brands and packaging desired by consumers. The results of this study may help to prepare a mulberry leaves the tea in a ready-to-drink package as an antioxidant-enriched product ready to be marketed.

\section{LITERATURE REVIEW}

Tea is a drink made by brewing leaves, leaf shoots, or tea plant leaves (Camellia sinesis) that are dried with hot water (Winarti, 2010). A study by Winarti (2010: 201) also states that the term tea is also used for beverages made of fruits, spices or other medicinal plants brewed. For example, rosella tea, chamomile tea, ginseng tea, etc. Tea made of ingredients that do not contain tea leaves are known as herbal teas. Somantri $(2011: 16)$ states that herbal tea is made of herbal ingredients or a mixture of some herbal ingredients that have health benefits. The chemical content of herbal tea depends on the ingredients used.

According to Somantri (2011: 23), antioxidant compounds contained in tea such as polyphenols, flavonoids, and catechins t can protect the body from the bad effects of free radicals. "The content of fluoride and tannins in tea can help reduce plaque formation and tooth decay" (Somantri, 2011: 26). The content of catechins in local tea (Indonesia) is among the highest so it has many benefits for the body. According to Orwa, et al. (2009), mulberry leaves contain vitamin B complex (except B12), vitamin C (200-300 mg / g), vitamin D, and flavonol. Mulberry leaves also contain many flavonoid compounds that act as antioxidants, namely morin $4.7 \mathrm{mcg} / \mathrm{g}$, quercetin, and kaempferol (Frank \& Orwell, 2013). Total flavonoid found in mulberry leaves 26,41 +/- 1,14 mg / g, total polyphenol about 260,00 +/- 20,00 mg / g GAE, and antioxidant effect of mulberry leaf IC50 20,10 +/- $0,78 \mathrm{mcg} / \mathrm{mL}$ on the DPPH test (Frank \& Orwell, 2013).

In addition, based on the research of Widowati (2011), the sappan wood extract contains terpenoid compounds, phenols, and flavonoids. Sappan wood extract also has a high antioxidant activity that is $80,46-89,13 \%$ (Widowati, 2011). Based on the previous study, the older the logs of sappan wood, the higher antioxidant activity (Hidayat \& Napitupulu, 2015). Nirmal, et al (2015) states that sappan wood contains water-soluble flavonoid compounds, namely brazilin, protosappanin, and hematoxylin. Brazilin is the main phytochemical compound found in sappan wood and is responsible for most of the sappan wood pharmacology activities. Brazilin is the source of the natural red dye contained in sappan wood. The best Brazilian content presents in the sappan wood liquid extract by boiling at $70{ }^{\circ} \mathrm{C}$ for 20 minutes (Farhana, et al, 2015). The stability of red extract on sappan wood is influenced by $\mathrm{pH}$, but it is quite stable with heat treatment (Rina, 2013).

The other ingredients of mulberry tea in this study is lime. Hariana (2013: 141) mentions that lime has pharmacological effects such as anti-fever, reducing cough, anti-inflammation, and antibacterial. In 100 grams of lime, there is vitamin C $27 \mathrm{mg}$, Calcium $40 \mathrm{mg}$, and phosphorus $22 \mathrm{mg}$ (Hariana, 2013). Lime also contains active compounds such as limonene, flavonoid, fiber, ascorbic acid (vitamin C), and citric acid which is beneficial for health (Puspaningtyas, 2013). 
The product mix is one factor that highly affects consumer preferences. The product mix is also the first variable that needs to be planned before the other variables because in the absence of the product there is nothing to be marketed. A product can be defined as everything that can be offered in the market to get attention, demand, usage or consumption that can fulfill customer desire or need (Kotler \& Armstrong, 2001: 346). Each product has certain characteristics so that a product can be distinguished from other similar products. These characteristics include product quality, brand, and packaging.

According to Ardiansyah (2011), the concept of quality in the field of food and beverages can be defined as a combination of product attributes that are considered organoleptically, such as color, texture, taste, and aroma. Color can be the first thing consumers judge when determining the quality of food and beverage products. According to Winarno (2004: 171), the color quality appears to be the most important factor that affects consumer preferences. The addition of sappan wood in the mulberry leaves tea is intended to improve the color of mulberry leaf tea because sappan wood is one of the natural food dyes.

The smell or smell can be one of the determinants of the quality of beverage or food products. There are thousands of smells and the sensitivity of the sense of smell is about 10,000 times of sense of sensitivity. According to Winarno (2004), odors can be recognized in the form of steam and in general, the smell received by the nose is a mixture of various smells or mixtures of four main odors, namely fragrant, sour, rancid, and charred. According to Winarno (2004), odors can be recognized in the form of steam and in general, the smell received by the nose is a mixture of various smells or mixtures of four major odors, namely fragrant, sour, rancid, and charred. Pain greatly affects consumer ratings of a food or beverage product. Winarno (2004: 206) states that chemical compounds, temperature, concentration, interaction with other components of taste are some factors that affect the taste of a drink or food.

The taste is very influential on consumer ratings on a food or beverage product. In general, it has been agreed that there are only four basic tastes, namely sweet, bitter, sour, and salty. Winarno (2004: 206) states that chemical compounds, temperature, concentration, interaction with other flavor components are some of the factors that affect the taste of a drink or food.

Brands and packaging have an important role to add value into a product (Sumarni \& Soeprihanto, 2003). Brands can function as the identity of a product and as a means to attract potential customers interest (Ambadar, et al., 2007). In addition, the provision of the brand also aims to make consumers easy to remember the products/services that will or have ever bought (Sumarni \& Soeprihanto, 2003: 277). Packaging is an act of wrapping or closing an item or a group of goods, while the package itself refers to the physical object itself (Klimchuck \& Krasovec, 2007: 34). Packaging serves to accommodate and protect the product during the distribution process, as a product identity, improving efficiency, protecting the adverse effects of its products, expanding product usage and marketing, enhancing the attractiveness of products, information, and advertising facilities, as well as comforting the user when consumed ( Kaihatu, 2014). Food packaging may be regarded as a contaminant that threatens food safety if packaging standards, 
packing methods, and type of packaging materials do not conform to packaged products (Alamsyah \& Gunarsa, 2011). Packaging materials commonly used to pack food and beverages are glass, paper and cardboard, cans, and plastic.

\section{METHODOLOGY}

This research is a descriptive-quantitative study. Preferences test is performed by 100 consumer-panelists. Panelists are selected by using an accidental sampling technique. Data collected in this study include consumer preferences on organoleptic characteristics (taste, aroma, and color) of mulberry leaves tea. The consumer preference test in this research uses five-item Likert scale, that is $1=$ does not like, 2 = rather dislike, 3 = normal, 4 = rather like, 5 = likes (Setyaningsih et al, 2010: 60). This study also identifies product attributes that are considered important by the panelists when they are consuming a ready-to-drink tea. Packaging used for mulberry leaf tea product tested is made of plastic PP (polypropylene) glass shaped with $360 \mathrm{ml}$ size and closed with cup sealer. The results of identification of product attribute considered important by consumers were analyzed using descriptive statistics.

The raw materials used in a ready-to-drink mulberry tea are mulberry leaves, sappan wood, water, sugar, salt, and lime. The basic formula of mulberry leaf tea is the result of modification of Nirmagustina sappan formula (2011). The formula of a ready-to-drink mulberry tea is shown in Table 1.

Table 1. The Formula of a Ready-to-drink Mulberry Tea
\begin{tabular}{|l|c|}
\hline Ingredients & $30 \mathrm{~g}$ \\
\hline Mulberry leaves & $3 \mathrm{~g}$ \\
Sappan wood & $1000 \mathrm{ml}$ \\
Water & $60 \mathrm{~g}$ \\
Sugar & $2 \mathrm{~g}$ \\
Salt & $10 \mathrm{ml}$ \\
\hline Lime
\end{tabular}

The procedure to make the mulberry leaves tea is as follows: a) Mulberry leaves should be young mulberry leaves, which are on the order of 3 to 7 from the top of the leaf. Selected mulberry leaves should be fresh, whole, no brown spots, and not damaged by insects or caterpillars. b) Mulberry leaves are washed with clean water that flows so that the dirt on the leaves can be removed. C). All ingredients are weighed or measured according to the prescribed formula to simplify the process and maintain a standard prescription. d). The next process is boiling (extraction). Mulberry leaves, sappan wood, sugar, and salt are added to boiled water. Then boiled at $90^{\circ} \mathrm{C}$ for 10 minutes. Extraction is performed for 10 minutes after the water boiled in order to make the active components that exist in the material can be extracted optimally. The extraction process is performed as simple as possible so that this mulberry leaf tea can be applied to the home industry. e). Next is a screening process that aims to separate extract and cooking waste. f). 
Then the lime juice is added to mulberry leaf tea to improve the color and aroma of tea.

\section{FINDINGS/DISCUSSION}

Based on the results of the research, it is known that the content of mulberry tea polyphenols ready to drink with the addition of $30 \%$ sappan wood approximately $1037 \mathrm{mg} / \mathrm{l}$. The content of polyphenols has fulfilled SNI 3143: 2011 which states that one of the quality requirements of tea drinks in the packaging is a polyphenol content of at least $400 \mathrm{mg} / \mathrm{l}$. The average content of polyphenol mulberry leaf tea ready to drink before getting the addition of wood sappan is $546 \mathrm{mg} / \mathrm{l}$. The average polyphenol content increases with the increasing percentage of wood addition sappan. Sappan wood contains water-soluble flavonoid compounds such as Brazilian, protosappanin, and hematoxylin (Nirmal, et al, 2015). The addition of wood sappan on mulberry leaves ready to drink tea which is boiled in hot water can extract the flavonoids contained in wood sappan. Therefore, the addition of wood sappan can increase the content of polyphenols found in mulberry leaf tea ready to drink. The more the amount of sappan wood added to mulberry leaves tea is ready to drink, the higher the polyphenol content will also increase.

The results of the consumer preferences on mulberry leaves tea is shown in Table 2.

Table 2. The Results of Consumer Preference Test

\begin{tabular}{|l|l|l|l|l|l|l|}
\hline Score & \multicolumn{2}{|l|}{$\begin{array}{l}\text { Preferences Level } \\
\text { on Color }\end{array}$} & \multicolumn{2}{l|}{$\begin{array}{l}\text { Preferences Level } \\
\text { on Aroma }\end{array}$} & \multicolumn{2}{l|}{$\begin{array}{l}\text { Preferences Level } \\
\text { on Taste }\end{array}$} \\
\hline & F & $\%$ & f & $\%$ & f & $\%$ \\
\hline $\mathbf{5}$ (likes) & 48 & $48 \%$ & 48 & $48 \%$ & 32 & $32 \%$ \\
\hline $\mathbf{4}$ (rather like) & 30 & $30 \%$ & 28 & $28 \%$ & 45 & $45 \%$ \\
\hline $\mathbf{3}$ (normal) & 15 & $15 \%$ & 7 & $7 \%$ & 13 & $13 \%$ \\
\hline $\mathbf{2}$ (rather dislike) & 7 & $7 \%$ & 15 & $15 \%$ & 4 & $4 \%$ \\
\hline $\mathbf{1}$ (does not like) & 0 & 0 & 2 & $2 \%$ & 6 & $6 \%$ \\
\hline
\end{tabular}

The hedonic quality test is also conducted in order to explain the results of consumer preference test on the ready-to-drink mulberry leaves tea. The results of hedonic quality of the ready-to-drink mulberry leave tea are shown in Table 3, Table 4, and Table 5.

Table 3. The Results of Hedonic Quality on Color

\begin{tabular}{|l|l|l|}
\hline Color Classification & \multicolumn{2}{|l|}{ Panelist Evaluation } \\
\hline & f & $\%$ \\
\hline Brownish Yellow & 27 & $27 \%$ \\
Light Brown & 52 & $52 \%$ \\
Brown & 17 & $17 \%$ \\
Dark Brown & 4 & $4 \%$ \\
Very Dark Brown & 0 & 0 \\
\hline
\end{tabular}


The results of the panelist's preference test on the taste of the mulberry leave tea shows that the majority of consumers likes the taste of the tea being tested. Based on the results of the study, panelists like the color of mulberry leaf tea with the addition of sappan wood sappan which is light brown than the yellowish brown or brown. According to Nugraheni (2012), "The color of bright food provides more appeal to consumers". The sappan wood contains brazilin which is the source of the natural red color, but the red color is unstable against $\mathrm{pH}$ change (Rina, 2013). The lower the $\mathrm{pH}$, the red color of the sappan wood decrease. The red color of sappan wood added to mulberry leaves tea interacts with lemon (acid $\mathrm{pH}$ ), which is one of the ingredients of mulberry leaves tea ready-to-drink. Therefore, the color of mulberry leaf tea is different due to the addition of sappan wood. Although the amount of lime used in mulberry leaves tea is the same, different amount of sappan wooden plates produces a different red color, so that the red color resulted from the interaction is also different. The more sappan wood added, less of diminishing red color occurred.

Table 4. The Results of Hedonic Quality on Aroma

\begin{tabular}{|l|l|l|}
\hline Aroma Classification & \multicolumn{2}{|l|}{$\begin{array}{l}\text { Panelist } \\
\text { Evaluation }\end{array}$} \\
\hline & $\mathbf{f}$ & $\%$ \\
\hline Strong Lime aroma & 39 & $39 \%$ \\
Enough lime aroma & 35 & $35 \%$ \\
Little bit lime aroma & 7 & $7 \%$ \\
Very little lime aroma & 11 & $11 \%$ \\
Doesn't have lime aroma & 8 & $8 \%$ \\
\hline
\end{tabular}

The results of the panelist preference test on the aroma of mulberry leaf tea showed that the majority of consumers liked the aroma of tea being tested. The results showed that mulberry and sappan leaves added to mulberry leaf tea did not affect the panelist's favorite level against the aroma of mulberry leaves ready to drink. The aroma that is on mulberry leaf tea ready to drink is a distinctive aroma of lime. Lime contains essential oils that cause lime has a distinctive aroma (Koensoemardiyah, 2010). Compounds that exist in sappan wood allegedly interact with the essential oil of lime, causing the essential oil content of lime yawning and causing a distinctive aroma of lime strong enough.

Table 5. The Results of Hedonic Quality on Taste

\begin{tabular}{|l|l|l|}
\hline Taste Classification & \multicolumn{2}{|l|}{$\begin{array}{l}\text { Panelist } \\
\text { Evaluation }\end{array}$} \\
\hline & $\mathbf{f}$ & $\%$ \\
\hline Not sour & 39 & $39 \%$ \\
Little bit sour & 35 & $35 \%$ \\
Sour Enough & 7 & $7 \%$ \\
Sour & 11 & $11 \%$ \\
Very sour & 8 & $8 \%$ \\
\hline
\end{tabular}

The results of the panelist preferences test on the taste of mulberry leaf tea show that the majority of consumers rather liked the taste of the tea being tested. 
Based on the results of the research, the taste of mulberry leaf tea with the addition of sappan wood is a little bit sour, which is generated from the lime added to the tea. The adding of lime into mulberry tea is aimed to gives a refresher into the mulberry tea since the original taste of this tea is slightly bitter.

Sour taste serves as a refresher in a beverage (Sarwono, 2001). Lime contains citric acid approximately 7-8\% which causes the lime taste sour (Sarwono, 2001). The sour taste of lime in the mulberry tea covers the bitter taste resulted from mulberry leaves and the sappan wood. The sour taste of mulberry leaf tea is getting higher when more sappan wood added. This phenomenon occurred because there are compounds in sappan wood that interacts with citric acid resulted from the lemon. This interaction causes many citric acids is decomposed so that it increases the acidic taste of the mulberry leaves tea.

The results of the research shown in Figure 1 describe the attributes that consumers are interested in while enjoying tea beverages in packaging. Based on Figure 1, it is known that five variables considered important by consumers in consuming ready-to-drink packaged tea are packaging, taste, price, color, and aroma.

Figure 1. The Important Attributes of A Ready-to-Drink Tea

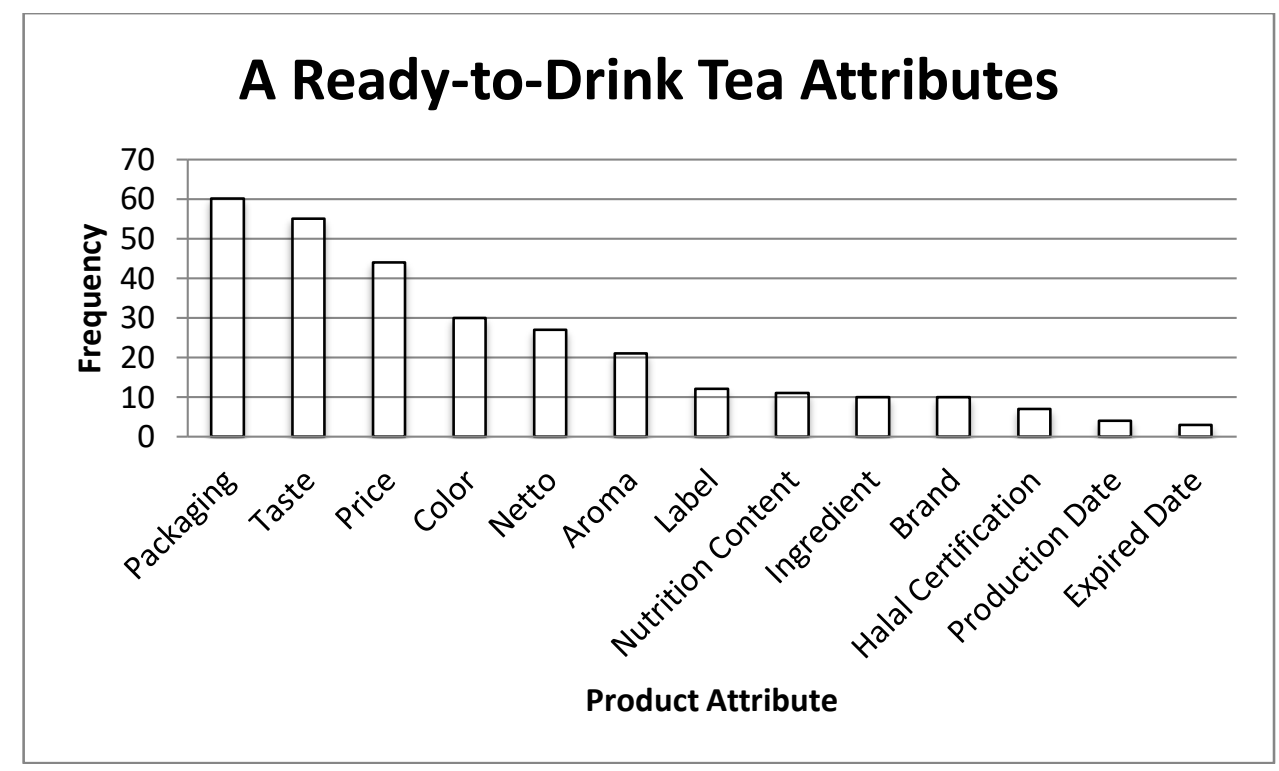

Based on Figure 1, taste, color, and aroma of a ready-to-drink tea are considered as important attributes by the consumer. These three attributes are also part of the hedonic quality properties of ready-to-drink tea products. In addition, refers to the results shown in Figure 1, in order to increase consumer preferences on mulberry leaf tea products, a producer needs to design a simple brand and packaging that have a harmonious blend of colors and shapes. A product logo consists of images, geometric shapes, and brand names that make the logo the center of attention. According to Adir, et al. (2012), a logo should be simple and easy to remember. The use of a slightly contrasting colors, such as purple and green color, gives the impression to the customer so that it can attract their attention. The green color can be a product symbol that is beneficial to health, while the purple 
color can symbolize mind, body, and soul for health-themed products (Klimchuck \& Krasovec, 2007).

Another thing that can be performed to improve consumer preferences on mulberry tea products is to determine the position of product identity (label) that enables to attract consumers attention. The position of the label on the product is divided into 3 parts, namely the brand, the composition information, and the picture to make the panelists focus on the description the consumers want to see. The position is the placement of design elements in a visual format (Klimchuck \& Krasovec, 2007: 80). The adjustment of the distance between letters in the brand design also makes the brand name looks united with the brand logo. This is in accordance with the opinion by Klimchuck \& Krasovec (2007: 90), which states that the adjustment between the letter distances can create visual harmony.

In addition to price, consumers also consider the quality of products they buy because consumers expect that the price equals (match) to the quality of the products they receive. Price may have different meanings to consumers depending on the consumer characteristics, situation and product quality (Larosa, 2011). Besides the raw material price, the product price differences are also influenced by the policy of each manufacturer in determining the price, such as the profit to be gained and the price competition among producers or sellers that ultimately creates a price range for a product. The factors that also affect the pricing is the market competition because the selling price of competitors is used as a parameter to determine the price. Consumers are also interested in getting the product at a price that is considered appropriate according to the perceived value of the product. According to Bachriansyah (2011), the price is worth the appropriate perceived value appropriate when the transaction occurs.

Consumer preferences formed before consumers decide to make a purchase. The preference of the consumer can be shaped by the mindset. Several underlying reasons that lead consumer mindset are the consumer experience and trust based on other experience. A consumer continues to use a particular product when satisfied and fit with the product performance. Therefore, a producer competes to adjust the products and services in order to fulfill consumer needs. The consumer may have different preferences, which helps explain why many producers offer products with a variety of characteristics.

\section{CONCLUSION}

The design of the mulberry leaf tea in a ready-to-drink package with the addition of sappan wood is a mulberry tea formula with $30 \%$ sappan wood enhancement that produces a brown color, a slightly typical aroma of lime, and a slightly sour taste. Based on the consumer preference, the hedonic quality which includes taste, color, and aroma of a ready-to-drink tea is considered as important attributes. The study also concludes that a producer needs to design a simple brand and packaging that have a harmonious blend of colors and shapes in order to increase consumer preferences on mulberry leaf tea products. The results of the panelist's preference test on taste and aroma of the mulberry leave tea shows that the majority of consumers likes the taste of the tea being tested. The adding of lime 
into mulberry tea have improved the consumer preferences on taste since it functions as a refresher into the mulberry tea since the original taste of this tea is slightly bitter.

\section{REFERENCES}

Adir, G., Adir, V. \& Pascu, N. E. 2012. Logo Design and The Corporate Identity. Procedia-Social and Behavioral Sciences, 51: 650-654.

Agustina, D. 2015. Orang Indonesia Minum 2 Miliar Liter Teh Kemasan Setahun. CNN Indonesia, (Online), (http://www.cnnindonesia.com/gayahidup/20151103151544-262-89179/orang-indonesia-minum-2-miliar-liter-tehkemasan-setahun/), diakses 24 Agustus 2016.

Alamsyah, Y. \& Gunarsa, D. 2011. Cerdas Mengemas Produk Makanan dan Minuman. Jakarta: AgroMedia Pustaka.

Ambadar, J., Abidin, M. \& Isa, Y. 2007. Mengelola Merek. Jakarta: Yayasan Bina Karsa Mandiri. Dari Google Books, (Online), (https://books.google.co.id), diakses 24 Agustus 2016.

Ardiansyah. 2011. Kualitas Pangan. Majalah 1000guru, (Online), (http://majalah1000guru.net/2011/01/kualitas-pangan/), diakses 15 Juni 2016.

Bachriansyah, R.A. 2011. Analisis Pengaruh Kualitas Produk, Daya Tarik Iklan, dan Persepsi Harga terhadap Minat Beli Konsumen pada Produk Konsumen Nokia (Studi Kasus pada Masyarakat di Kota Semarang. Skripsi tidak diterbitkan. Semarang: Universitas Diponegoro.

Farhana, H., Maulana, I. T. \& Kodir, R. A. 2015. Perbandingan Pengaruh Suhu dan Waktu Perebusan Terhadap Kandungan Brazilin pada Kayu Secang (Caesalpinia Sappan L.). Prosiding Penelitian SPeSIA Unisba 2015. ISSN 2460-6472.

Frank, K. \& Orwell, S. 2013. Morus Alba, (Online), (https://examine.com/supplements/morus-alba/).

Hariana, A. 2013. 262 Tumbuhan Obat dan Khasiatnya. Jakarta: Penebar Swadaya.

Hidayat, S. \& Napitupulu, R. M. 2015. Kitab Tumbuhan Obat. Jakarta: AgriFlo (Penebar Swadaya Group).

Kaihatu, T. S. 2014. Manajemen Pengemasan. Yogyakarta: ANDI.

Klimchuck, M. R. \& Krasovec, S. A. 2006. Desain Kemasan. Terjemahan Bob Sabran. 2007. Jakarta: Erlangga.

Koensoemardiyah. 2010. A to Z Minyak Atsiri untuk Industri Makanan, Komestik, dan Aromaterapi. Yogyakarta: ANDI.

Kotler, P. \& Amstrong, G. 2001. Prinsip-Prinsip Pemasaran (Jilid 1, Edisi 8). Terjemahan Damos Sihombing. Jakarta: Erlangga.

Larosa, S.R. 2011. Analisis Pengaruh Harga, Kualitas Produk, Dan Lokasi Terhadap Keputusan Pembelian. Skripsi tidak diterbitkan. Semarang: Universitas Diponegoro.

Nirmagustina, D. E., Zulfahmi \& Oktafrina. 2011. Sifat Organoleptik dan Kandungan Total Fenol Minuman Rempah Tradisional (Minuman Secang). Jurnal Teknologi Industri dan Hasil Pertanian, 16 (1): 22-33.

Nirmal, N. P., Rajput, M. S., Prasad, R. G.S.V. \& Ahmad, M. 2015. Brazilin from Caesalpinia Sappan Heartwood and Its Pharmacological Activities: A Review. Asian Pacific Journal of Tropical Medicine, 8 (6): 421-430. 
Nugraheni, M. 2012. Pewarna Alami Makanan dan Potensi Fungsionalnya. Makalah disajikan dalam Seminar Nasional Peningkatan Kompetensi Guru dalam Menghadapi UKG, Yogyakarta, Februari 2012, (Online), (http://staff.uny.ac.id/dosen/dr-mutiara-nugraheni-stp-msi), diakses 23 Februari 2017.

Orwa, C., Mutua, A., Kindt, R., Jamnadass, R., Simons, A. 2009. Agroforestree Database: A Tree Reference and Selection Guide Version 4.0, (Online), (http://www.worldagroforestry.org/treedb/AFTPDFS/Morus_alba.PDF), diaccessed on 8 Maret 2016.

Puspaningtyas, D. E. 2013. The Miracle of Fruits. Jakarta: Agromedia Pustaka.

Riadi, M. 2014. Senyawa Polifenol pada Tanaman, (Online), (http://www.kajianpustaka.com/2014/06/senyawa-polifenol-padatanaman.html), diakses 24 Agustus 2016.

Rina, O. 2013. Identifikasi Senyawa Aktif dalam Ekstrak Etanol Kayu Secang (Caesalpinia Sappan L.). Prosiding Semirata FMIPA Universitas Lampung, 215-218.

Sarwono, B. 2001. Khasiat dan Manfaat Jeruk Nipis. Jakarta: Agromedia Pustaka.

Somantri, R. 2011. Kisah dan Khasiat Teh. Jakarta: Gramedia Pustaka Utama.

Sumarni, M. \& Soeprihanto, J. 2003. Pengantar Bisnis (Dasar-Dasar Ekonomi Perusahaan). Yogyakarta: Liberty.

Swastha, B. \& Sukotjo, I. 2002. Pengantar Bisnis Modern. Yogyakarta: Liberty.

Widowati, W. 2011. Uji Fitokimia dan Potensi Antioksidan Ekstrak Etanol Kayu Secang (Caesalpinia Sappan L.). JKM, 11 (1): 23-31.

Winarno, F. G. 2004. Kimia Pangan dan Gizi. Jakarta: Gramedia Pustaka Utama.

Winarsi, H. 2007. Antioksidan Alami \& Radikal Bebas. Yogyakarta: Kanisius.

Winarti, S. 2010. Makanan Fungsional. Yogyakarta: Graha IImu. 